\section{Australian inquiry in London}

THE London hearing of the Australian Royal Commission investigating the safety of the British nuclear tests in Australia in the 1950s opened last Thursday with a strong complaint that the British government had failed to live up to its promise of cooperation with the commission's work. Mr Justice James McClelland said that the conduct of the government did not match its assurances given in advance.

The British government decided only in December to be legally represented before the Australian commission. The decision seems to have been made reluctantly, after the commission publicly accused the British government of dragging its feet.

Mr Justice McClelland said that "since the British know so much more than we do about what they were about in our country at that time", cooperation should mean not simply giving access to a mountain of documents, but "giving positive assistance in bringing to light anything of relevance which those documents may disclose". McClelland added that evidence to be heard suggests that the British government told the Australian authorities virtually nothing about what they were doing in Australia during the tests. He also expressed surprise that the British government had insisted that the Australian government must waive its right to prosecute witnesses for perjury, as a condition of allowing the commission to sit in Britain. Such limitations, he said, "sit uneasily with the offer of cooperation and disclosure already made'. Mr Robin Auld, for the British government, guaranteed that relevant documents would be produced, and that witnesses including key British personnel responsible for the tests would be made available.

Six ex-servicemen gave evidence to the commission on Monday. Mr Barrie Roberts, of Walsall, had been posted to the Maralinga range, where he said he did not recall being given any particular warnings about the radiation hazard. "We were issued with a handbook which contained all sorts of information, including a section on health. It told you how to deal with snake bites, and warned you about drinking spirits in desert temperatures, but there was nothing in the health section about radiation."

Mr Norman O'Fee, of Eynesbury (Cambridgeshire), joined the Royal Air Force in 1947 , and in 1955 was with 24 Squadron flying RAF Hastings aircraft in support of tests at Maralinga. After one of the "Buffalo" explosions, the first air-drop, he flew a group of scientists over ground-zero for about two hours. The plane carried test equipment, and criss-crossed the area at various altitudes. "We were wearing ordinary flying clothing with no safety gear. I could see quite clearly the circle of glazed sand beneath us", Mr O'Fee told the hearing, saying that he had developed cataracts in both eyes between 1981 and 1983. He considers these may have been due to radiation.

Mr Michael Stephens, one of a meteorological team of eight, joined HMS Campania in 1952 and sailed to the Monte Bello islands for what was later confirmed by Dr William Penney (now Lord Penney), one of the scientists on board, to have been an atom-bomb test. Mr Stephens described on Monday a lecture he attended at

\section{South Pacific tests}

WHILE Britain faces Australian ire over the effects of nuclear testing in Australia in the 1950s (see p.86), France is also in the dingo-house over its continued testing of nuclear weapons on Mururoa atoll near Tahiti. Last month, the temperature of the Franco-Australian conflict was raised when President François Mitterand accused Australia of solving the problem of the aborigines "by killing them".

This seems to have been a tit-for-tat remark after Australian criticism of French "colonialism"' in New Caledonia (where many French Algerians emigrated after Algerian independence, and where some Caledonian aboriginals were recently ambushed and shot). But it seems certain to backfire, increasing Australian pressure on France to stop underground testing of 8-10 nuclear weapons a year.

So far, Australia has applied only one sanction to France: the postponement of shipments of uranium, amounting to a few hundred tons of ore a year. But the sanction is weak. France has recently diversified its sources of supply and, moreover, there is a glut of uranium on the market. In fact, Electricite de France, the French utility buying the Australian uranium, readily agreed to the postponement, which will last until France stops bomb-testing in the Pacific.

Although further sanctions are not for the time being contemplated in Australia, 18 Pacific nations including Australia and New Zealand are drawing up an international convention which should make the joint economic zones of signatories a "nuclear free area", to exclude nuclear dumping, storage and weapons testing. The terms of this convention are not likely to be softened by M. Mitterrand's accusations.

Nevertheless, when tempers cool, some thought might be given to recent scientific assessments of the environmental impact of the Muroroa tests by a scientific mission from New Zealand, Australia and Papua New Guinea, which allayed immediate concern about short-term effects. Moreover, an exhaustive recent review* concluded that:

which Dr Penney explained the need for the tests, saying that "I remember nothing specific about the danger from radioactivity; nothing he said alerted me to any possible hazard from radiation".

The hearing was told on Monday that a tentative list of about 26 witnesses for the British government will be available to the commission. The British government was also formally asked to produce logs of the Varsity aircraft used in the Buffalo and Antler test series. The Varsities carried out flights intended to monitor the test sites for aborigines some time before detonations took place.

Susan Watts

\title{
Mitterrand in the dingo-house
}

For the South Pacific region, the average annual effective dose equivalent from natural sources of ionizing radiation is approximately 2,000 microsievert, only half the world average;

- Exposure to artificial sources, mainly the radionuclides formed during weapons tests in the atmosphere, is on the average perhaps two to three times lower in the South Pacific than for the world as a whole.

The exceptions are Niue Island, "a documented example of unusually high natural radioactivity", Guam (which may also have high natural levels) and certain of the Marshall Islands still contaminated by fall-out from US nuclear tests.

However, while the UNEP report considers the French underground tests to be safer than tests above ground, "one should be particularly concerned at the possible long-term effects, such as leakage of radionuclides into the ocean, especially if the testing programme... is to continue".

The UNEP technical group preparing the report, chaired by Dr Michael Bacon of the Woods Hole Oceanographic Institution in the United States, believes that past environmental assessments and publication of results on Mururoa previous to the recent scientific mission have been "inadequate". Bacon considers it "interesting" that the French recently began conducting tests within the Mururoa Lagoon, rather than in the atoll itself, as was past practice. French scientists are concerned with the danger of tsunami-like waves produced by sediment slides on the atoll slopes.

Nevertheless, the UNEP technical group concludes that "the present nuclear weapons testing... involve[s] only a small, quite possibly non-existent risk to human health and the environment in the South Pacific region". The group says that there is little "scientific basis for judging these activities to be unacceptable", but acknowledges that "legal, political and moral principles" may be more relevant.

Robert Walgate

* Radioactivity in the South Pacific United Nations Environment Programme Reports and Studies no. 40 (1984). 